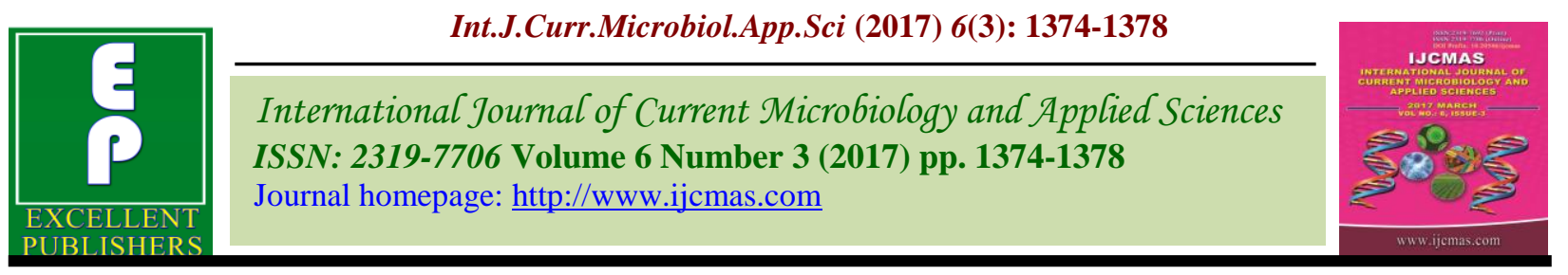

Original Research Article

https://doi.org/10.20546/ijcmas.2017.603.159

\title{
In vitro Effect of Bio- Control Agents and Selected Botanical against Root Rot (Rhizoctonia solani Kuhn) of Chilli (Capsicum annuum L.)
}

\author{
Vijay Babal*, Dinesh Kumar, Harish Kumar, Kuldeep Singh and Abhilasha A. Lal
}

Department of Plant Pathology, Sam Higginbottom Institute of Agriculture, Technology and Sciences, (Deemed-to-be University) Allahabad, U. P., India

*Corresponding author

\section{A B S T R A C T}

Keywords

Capsicum annuum, Rhizoctonia solani,

Trichoderma viride,

Pseudomonas

fluorescens,

Trichoderma

harzianum, Neem

leaf extract, Neem

oil, Carbendazim,

Root rot.

Article Info

Accepted:

20 February 2017

Available Online:

10 March 2017
To manage the disease an investigation at the Department of Plant Pathology, SHIATS-DU, Allahabad was carried out to evaluate the effect of bio-agents viz. Trichoderma viride@2\%,Pseudomonas fluorescens @ 2\%,T. harzianum @2\%, botanical viz.neem leaf extract @ 5\%,neem oil @ 5\% and fungicide viz. carbendazim @ 0.2\% against $R$. solani under invitro condition by dual culture and poisoned food technique. All the bioagents and botanical were evaluated singly. All the treatments significantly inhibited the mycelial growth of $R$. solani as compared to untreated check. Maximum inhibition per cent of mycelia growth of Rhizoctonia solani was recorded in Trichoderma viride (82.82\%) followed by neem oil $(82.69 \%)$, P. fluorescens (79.26\%), T. harzianum (77.98\%) and neem leaf extract $(73.79 \%)$ as compared to treated check (Carbendazim) $(87.78 \%)$ and untreated check $(0 \%)$.

\section{Introduction}

Chilli (Capsicum annuum L.) a member of family solanaceae is mainly cultivated for its green fruits as vegetable and for the dry chilli as the spice of commerce. It is believed to be originated from South America. It has also acquired a great importance because of the presence of 'oleoresin', which permits better distribution of color and flavor in foods (Chattopadhyay et al., 2011). Thus, chilli has diverse uses as spice, condiment, culinary supplement, medicine, vegetable and ornamental plant. The pharmaceutical application of capsaicinoid is attributed to its antioxidant, anticancer, antiarthritic, and analgesic properties (Akbar et al., 2010).

India is largest exporter and major destinations are Malaysia, Sri Lanka, Bangladesh and Indonesia. Exports have touched record high of 2.81 lakh tonnes in 2012-13 and during April-Jun 2013 exports were 65500 tonnes. India earns about 2000 corers every year on export of chilli (Anonymous, 2014). 
Chilli is known to suffer from as many as 83 different diseases, of which more than 40 are caused by fungi (Rangaswami, 1958). Among the fungal diseases, root rot of chilli caused by $R$. solani has attained the economic importance. The disease is difficult to manage as the pathogen has long saprophytic survival ability in soil. It can cause up to 33.2 percent disease incidence of the seedling in greenhouse condition and in main field 40.2 percent (Rini and Sulochana, 2006).

\section{Materials and Methods}

The in vitro experiment was laid out in completely randomized design (CRD) with six treatments bioagents viz. Trichoderma viride @2\%, T. harzianum @2\%, Pseudomonas fluorescens @ 2\% and botanical viz. neem leaf extract, neem oil and fungicide viz. carbendazim @0.2\% and three replications including untreated check.

\section{Poisoned food technique}

Nine millimetre diameter disc of Rhizoctonia solani was kept at the centre of each Petri plate containing the extracts and fungicide of required concentration dissolved in PDA. Three replications were maintained. The plates were incubated at $27 \pm 1^{\circ} \mathrm{C}$ for seven days and colony diameter was recorded. Per cent inhibition of mycelial growth was calculated by using the formula given by Vincent (1947).

\section{In-vitro evaluation of bio-agents}

Antagonistic microorganisms like, Trichoderma harzianum, Trichoderma viride and Pseudomonas fluorescens were evaluated for their antagonistic properties against Rhizoctonia solani by dual culture technique.
Twenty millilitre of PDA was poured into sterile Petri plates. Fungal antagonists were evaluated by inoculating the pathogen at one side of the Petri plate and the antagonist was inoculated at exactly opposite side of the same plate by leaving 3-4 cm gap. For this actively growing cultures were used. In case of bacterial antagonist's evaluation, two mycelial discs of pathogen were inoculated and bacterial antagonist was streaked in the centre of the plate. One control was maintained where in only test fungus was grown. The treatments were replicated three times. The plates were incubated for seven days at $27 \pm 1^{\circ} \mathrm{C}$ after incubation, the colony diameter of Rhizoctonia solani was recorded. Per cent inhibition was calculated by using the formula given by Vincent (1947).

Per cent inhibition of colony $=$

$$
\begin{gathered}
\text { C - T } \\
\text { C }
\end{gathered}
$$

Where:

$\mathrm{C}=$ Colony diameter in control

$\mathrm{T}=$ Colony diameter in treatment

\section{Results and Discussion}

\section{Mycelial growth (cm) at 168 hours after inoculation}

At 168 hours after inoculation Minimum mycelial growth $(\mathrm{cm})$ was recorded in $\mathrm{T}_{4^{-}}$ Trichoderma viride $(1.35 \mathrm{~cm})$ followed by $\mathrm{T}_{2}$ Neem oil $(1.36 \mathrm{~cm}), \mathrm{T}_{5^{-}}$Pseudomonas fluorescens $(1.63 \mathrm{~cm}), \mathrm{T}_{3^{-}}$T. harzianum $(1.73$ $\mathrm{cm}), \mathrm{T}_{1}-$ Neem leaf extract $(2.06 \mathrm{~cm})$ as compared to treated check $\mathrm{T}_{6^{-}}$Carbendazim $(0.96 \mathrm{~cm})$ and untreated check $\mathrm{T}_{0^{-}}(7.86 \mathrm{~cm})$. All the treatments were found statistically significant over untreated check. 
Table.1 Details of the treatments (in-vitro) with name and concentration

\begin{tabular}{|c|l|c|c|c|c|c|c|}
\hline S. No. & \multicolumn{1}{|c|}{ Treatments } & \multicolumn{3}{|c|}{ Replications } & $\begin{array}{l}\text { Conc. } \\
(\%)\end{array}$ & References & Technique used \\
\hline $\mathrm{T}_{0}$ & Untreated check & $\mathrm{R} 1$ & $\mathrm{R} 2$ & $\mathrm{R} 3$ & ---- & ---- & ---- \\
\hline $\mathrm{T}_{1}$ & Neem leaf extract & $\mathrm{R} 1$ & $\mathrm{R} 2$ & $\mathrm{R} 3$ & $5 \%$ & Rajput et al. $(2011)$ & Poisoned food technique \\
\hline $\mathrm{T}_{2}$ & Neem oil & $\mathrm{R} 1$ & $\mathrm{R} 2$ & $\mathrm{R} 3$ & $5 \%$ & Rajput et al. (2011) & Poisoned food technique \\
\hline $\mathrm{T}_{3}$ & $\begin{array}{l}\text { Trichoderma } \\
\text { harzianum }\end{array}$ & $\mathrm{R} 1$ & $\mathrm{R} 2$ & $\mathrm{R} 3$ & $2 \%$ & Malhotra et al. (2011) & Dual culture technique \\
\hline $\mathrm{T}_{4}$ & $\begin{array}{l}\text { Trichoderma } \\
\text { viride }\end{array}$ & $\mathrm{R} 1$ & $\mathrm{R} 2$ & $\mathrm{R} 3$ & $2 \%$ & Malhotra et al. (2011) & Dual culture technique \\
\hline $\mathrm{T}_{5}$ & $\begin{array}{l}\text { Pseudomonas } \\
\text { fluorescens }\end{array}$ & $\mathrm{R} 1$ & $\mathrm{R} 2$ & $\mathrm{R} 3$ & $2 \%$ & Malhotra et al. (2011) & Dual culture technique \\
\hline $\mathrm{T}_{7}$ & $\begin{array}{l}\text { Treated check } \\
\text { (Carbendazim) }\end{array}$ & $\mathrm{R} 1$ & $\mathrm{R} 2$ & $\mathrm{R} 3$ & $0.2 \%$ & Rehman et al. (2013) & Poisoned food technique \\
\hline
\end{tabular}

Table.2 Mycelial growth $(\mathrm{cm})$ of Rhizoctonia solani as affected by different treatments at different hours interval

\begin{tabular}{|c|l|c|c|c|c|c|c|c|}
\hline \multicolumn{1}{|c|}{ Treatments } & $\begin{array}{c}\mathbf{2 4} \\
\text { hrs. }\end{array}$ & $\begin{array}{c}\mathbf{4 8} \\
\text { hrs. }\end{array}$ & $\begin{array}{c}\mathbf{7 2} \\
\text { hrs. }\end{array}$ & $\begin{array}{c}\mathbf{9 6} \\
\text { hrs. }\end{array}$ & $\begin{array}{c}\mathbf{1 2 0} \\
\text { hrs. }\end{array}$ & $\begin{array}{c}\mathbf{1 4 4} \\
\text { hrs. }\end{array}$ & $\begin{array}{c}\mathbf{1 6 8} \\
\text { hrs. }\end{array}$ \\
\hline $\mathrm{T}_{0}$ & Untreated check & 2.82 & 2.86 & 4.42 & 5.42 & 6.12 & 7.12 & 7.86 \\
\hline $\mathrm{T}_{1}$ & Neem leaf extract & 1.35 & 1.41 & 1.53 & 1.65 & 1.81 & 1.95 & 2.06 \\
\hline $\mathrm{T}_{2}$ & Neem oil & 0.30 & 0.46 & 0.76 & 0.82 & 1.0 & 1.10 & 1.36 \\
\hline $\mathrm{T}_{3}$ & Trichoderma harzianum & 1.18 & 1.23 & 1.28 & 1.46 & 1.53 & 1.66 & 1.73 \\
\hline $\mathrm{T}_{4}$ & Trichoderma viride & 0.73 & 0.85 & 0.88 & 1.06 & 1.15 & 1.21 & 1.35 \\
\hline $\mathrm{T}_{5}$ & Pseudomonas fluorescens & 1.15 & 1.21 & 1.28 & 1.36 & 1.45 & 1.51 & 1.63 \\
\hline $\mathrm{T}_{6}$ & Treated check (carbendazim) & 0 & 0.20 & 0.20 & 0.30 & 0.60 & 0.90 & 0.96 \\
\hline & F-test & S & S & S & S & S & S & S \\
\hline & S. Ed. $( \pm)$ & $\mathbf{0 . 6 9 6}$ & $\mathbf{0 . 8 5 7}$ & $\mathbf{0 . 8 2 9}$ & $\mathbf{0 . 7 4 5}$ & $\mathbf{0 . 6 1 7}$ & $\mathbf{0 . 8 1 9}$ & $\mathbf{0 . 4 5 0}$ \\
\hline & C. D. (5\%) & $\mathbf{2 . 1 1 0}$ & $\mathbf{2 . 5 9 9}$ & $\mathbf{2 . 5 1 3}$ & $\mathbf{2 . 2 6 1}$ & $\mathbf{1 . 8 7 2}$ & $\mathbf{2 . 4 8 4}$ & $\mathbf{1 . 3 6 5}$ \\
\hline
\end{tabular}

Table.3 Per cent inhibition of Rhizoctonia solani as affected by different treatments

\begin{tabular}{|c|l|c|}
\hline \multicolumn{2}{|c|}{ Treatments } & Per cent inhibition \\
\hline $\mathrm{T}_{0}$ & Untreated check & 0 \\
\hline $\mathrm{T}_{1}$ & Neem leaf extract & 73.79 \\
\hline $\mathrm{T}_{2}$ & Neem oil & 82.69 \\
\hline $\mathrm{T}_{3}$ & Trichoderma harzianum & 77.98 \\
\hline $\mathrm{T}_{4}$ & Trichoderma viride & 82.82 \\
\hline $\mathrm{T}_{5}$ & Pseudomonas fluorescens & 79.26 \\
\hline $\mathrm{T}_{6}$ & Treated check (carbendazim) & 87.78 \\
\hline
\end{tabular}


Fig.1 Mycelial growth (cm) of Rhizoctonia solani 7 days after incubation as affected by different treatments

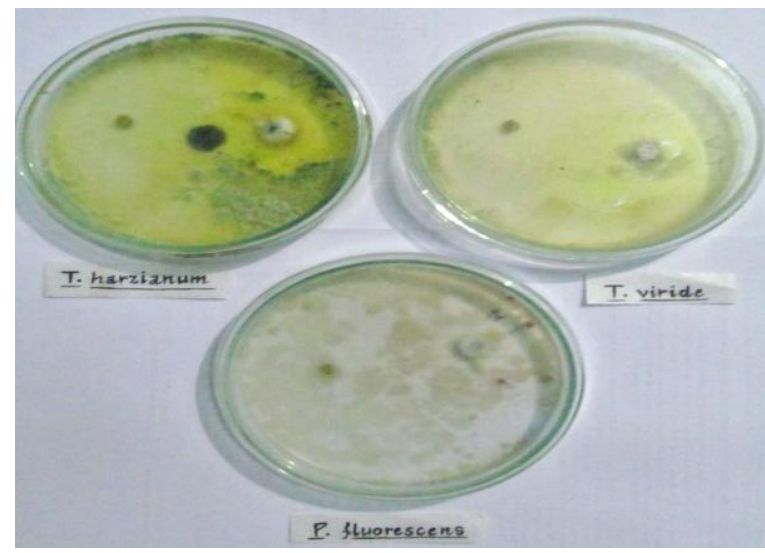

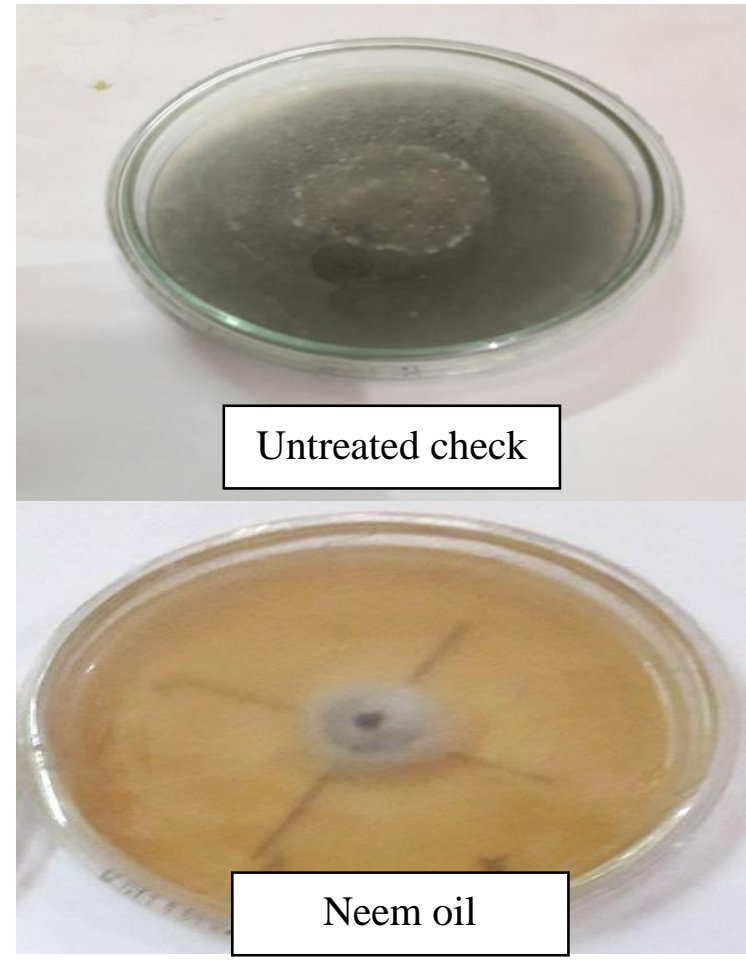

Per cent inhibition of Rhizoctonia solani as affected by different treatments

At maximum per cent inhibition was recorded in $\mathrm{T}_{4^{-}}$Trichoderma viride $(82.82 \%)$ followed by $\mathrm{T}_{2^{-}}$ Neem oil (82.69), $\mathrm{T}_{5^{-}}$Pseudomonas fluorescens (79.26 \%), $\mathrm{T}_{3^{-}}$T. harzianum $(77.98 \%), \mathrm{T}_{1^{-}}$Neem leaf extract $(73.79 \%)$ as compared to treated check $\mathrm{T}_{6^{-}}$Carbendazim $(87.78 \%)$ and untreated check $\mathrm{T}_{0^{-}}(0)$.

Antagonistic activity of Trichoderma viride,

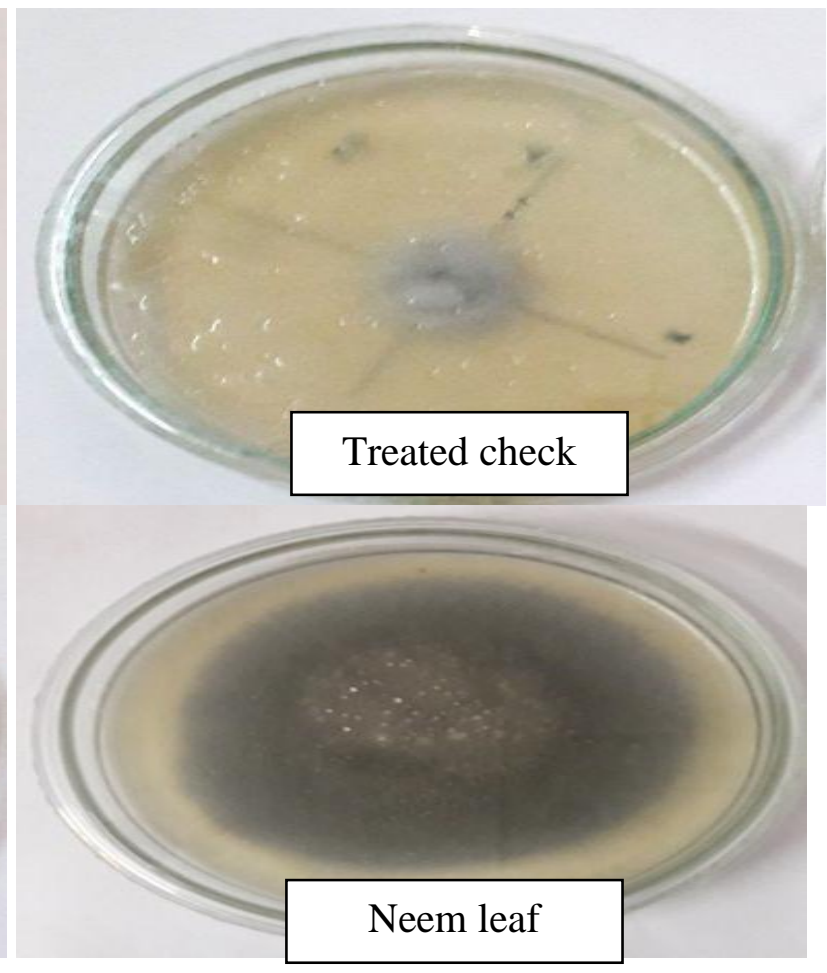

Pseudomonas fluorescens and T. harzianum were investigated by dual culture method on PDA. Data reveals that, $T$. viride, $P$. fluorescens were potential antagonists of Rhizoctonia solani forming a clear zone of inhibition. On microscopic examination hyphae of antagonists were observed coiling and oppressed around hyphae of $R$. solani. All the treatments were found statistically significant over untreated check. The results of the present study are in accordance to the findings of the Madhavi and Bhattiprolu (2011), Malhotra et al., (2011), Tariq et al., 
(2009), Abdel-Monaim et al., (2012) and Subash et al., (2013). They reported that the inhibition of $R$. solani due to Trichoderma spp. may have been due to secretion of extracellular cell degrading enzymes such as chitinase B-1, 3-glucanase, cellulose and lectin, which may have helped mycoparasites in the colonization of their host. The inhibition of pathogen may also be attributed to the production of secondary metabolites by antagonists such as glioviridin, viridian and gliotoxin (Shabir and Rubina, 2010; Kalmesh and Gurjar, 2002; Patel et al., 2014; Sab et al., 2014).

\section{References}

Abdel-Monaim, M.F., Abdel-Gaid, M.A.W. and Armanious, H.A.H. 2012. Effect of chemical inducers on root rot and wilt diseases, yield and quality of tomato, Int. J. Agric. Sci., 2(7): 210-220.

Akbar, N. Ahmad, H. Ghafoor, S. and Khan L.A. 2010. Phylogeny and Genetic diversity Studies in Capsicum Using Seed Storage. Curr. Res. J. Bio. Sci., 2: 250-252.

Anonymous. 2014. Chilli market outlook, research desk inditrade derivatives and commodities Ltd. jrgcomresearch@inditrade.com.

Chattopadhyay, A. Sharangi, A.B., Dai N. and Dutta, S. 2011. Diversity of genetic resource and genetic association analyses of green and dry chillies of Eastern India. Chilean J. Agri. Res., 71: 350-356.

Kalmesh, M. and Gurjar, R.B.S. 2002. Evaluation of different fungal antagonistic Plant extracts and oil cakes against Rhizoctonia solani causing stem rot of chilli seedlings. Ann. Pl. Protec. Sci., 10(2): 319-322.

Madhvi, B.G., and Bhattiprolu, S.L. 2011. Integrated disease management of dry root rot of chilli incited by Sclerotium rolfsii (SACC. Int. J. Pl., Animal Envir. Sci., 1(2):
31-37.

Malhotra, A., Agarwal, T. and Trivedi, P. C. 2011. In vitro efficacy of various fungal and bacterial antagonists against Rhizoctonia solani, causal agent of damping off disease in Capsicum annuum. Int. J. Pharma. Biol. Sci., 3(2): 288-292.

Patel, M.D., Lal, A.A. and Singh, P.P. 2014. Efficacy of certain bio agent and fungicides against root rot of chilli (Capsicum annuum L.) The Bioscan, 9(3): 1273-1277.

Rangaswami, G. 1958. An agar block technique for isolating soil micro-organisms with special reference to pythiaceous fungi. Sci. Culture, pp: 24-85.

Rini, C.R. and Sulochana, K.K. 2006. Management of seedling rot of chilli (Capsicum annuum L.) using Trichoderma sp and flourecent Pseudomonas. J. Tropic. Agric., 44(1-2): 79-82.

Sab, J., Nagaraja, A. and Naganna, G. 2014. Efficacy of bio-pesticides against Sclerotium rolfsii Sacc. causing collar rot of chickpea (Cicer arietinum L.. The Bioscan, 9(1): 335-339.

Shabir and Rubina, L. 2010. Biological control of damping-off disease of cabbage caused by Rhizoctonia solani Kuhn. Appl. Biol. Res., 12: 38-41.

Subash, N., Meenakshisundarm, M. and Sasikumar, C. 2013 a. In-vitro evaluation of different strains of Trichoderma harzianum as bio-control agents of chilli. Int. J. Biol. Pharma. Allied Sci., 2(2): 495-500.

Tariq, S., Khan, R., Sultana, V., Ara, J. and Haque, S.E. 2009. Utilization of endo-root Fluorescent Pseudomonas of chilli for the management of root disease of chilli. Pak. J. Bot., 41(6): 3191-3198.

Vincent, J.M. 1947. Distortion of fungal hyphae in the presence of certain inhibitors, Nature, 159: 850 .

\section{How to cite this article:}

Vijay Babal, Dinesh Kumar, Harish Kumar, Kuldeep Singh and Abhilasha A. Lal. 2017. In vitro Effect of Bio- Control Agents and Selected Botanical against Root Rot (Rhizoctonia solani Kuhn) of Chilli (Capsicum annuum L.). Int.J.Curr.Microbiol.App.Sci. 6(3): 1374-1378.

doi: https://doi.org/10.20546/ijcmas.2017.603.159 